\title{
Demonstration of a Deficiency of Glucocerebroside-cleaving Enzyme in Gaucher's Disease*
}

\author{
Roscoe O. Brady, $\dagger$ Julian N. Kanfer, Roy M. Bradley, and \\ DAVID SHAPIRO \\ (From the Laboratory of Neurochemistry, National Institute of Neurological Diseases and \\ Blindness, Bethesda, Md., and the Department of Organic Chemistry, Weizmann \\ Institute of Science, Rehovoth, Israel)
}

The accumulation of abnormal quantities of glucocerebroside in the reticuloendothelial cells of patients with Gaucher's disease is well documented (2-7). Previous studies in this laboratory indicated no abnormality in cerebroside formation in spleen tissue obtained from patients with Gaucher's disease (8). These observations suggested that the biochemical lesion in these patients might be on the pathway of cerebroside catabolism. To pursue such investigations, we chemically synthesized glucocerebroside- ${ }^{14} \mathrm{C}$ labeled in carbon atom 1 of the D-glucose portion of the cerebroside molecule (9). With this material, it was possible to demonstrate and partially purify an enzyme in human spleen tissue that catalyzes the hydrolysis of the glycosidic bond of the cerebroside molecule. The products of the reaction catalyzed by the most highly purified enzyme preparation were shown to be glucose and ceramide ( $N$-acylsphingosine) (9).

When this information became available, studies were undertaken to determine the level of the glucocerebroside-cleaving enzyme in human spleen tissue obtained from patients with various conditions. The present report describes the results obtained in these experiments and presents evidence of a marked attenuation of glucocerebrosidecleaving activity in the spleen of patients with Gaucher's disease.

* Submitted for publication January 10, 1966; accepted March 16, 1966.

A portion of this work was reported in a preliminary communication (1).

A portion of this work was performed under section 104(K) of Public Law 480, 83rd Congress, agreement no. 42515.

$\dagger$ Address requests for reprints to Dr. Roscoe O. Brady. National Institutes of Health, Bethesda, Md. 20014.

\section{Methods}

Clinical material. All of the spleen tissue used in this series was obtained at operation. In the control group, splenomegaly was present only in the three patients with hemolytic anemia. The largest spleen was obtained from patient $W R$ and weighed 2,300 g. A varying degree of splenomegaly was present in all of the patients with Gaucher's disease. The largest spleen, weighing $1,100 \mathrm{~g}$, was obtained from patient $\mathrm{AK}$. The diagnosis of Gaucher's disease was established by Jena-Giemsa staining of the tissue specimens. In all instances, bone marrow aspiration also revealed the presence of Gaucher's cells. Only patient SZ, with the infantile form of Gaucher's disease, showed any neurological abnormality.

Assay procedure. Each of the specimens of spleen tissue was packed in dry ice within 5 minutes after excision. The samples were thawed and assayed for glucocerebroside-cleaving activity within 24 hours. Control studies indicated that this enzymatic activity did not diminish appreciably under these conditions. However, there was a gradual decrease in activity of about $5 \%$ per day on storing the frozen human tissue at $-15^{\circ} \mathrm{C}$ (9).

Cell-free extracts of the thawed tissue were prepared by mincing the tissues and homogenizing them in $2 \mathrm{vol}$

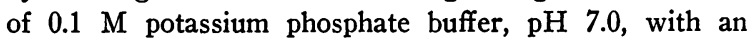
all glass TenBroeck homogenizer. The suspensions were filtered through two layers of cheesecloth and centrifuged at $600 \times g$ for 12 minutes. The $600 \times g$ supernatant suspensions were then centrifuged at $100,000 \times g$ for 1 hour. The activity of the glucocerebroside-cleaving enzyme was assayed on samples of the high speed supernatant solutions. The incubation mixtures contained 50 $\mu$ moles of potassium phosphate buffer, $\mathrm{pH} 7.0,0.140$ $\mu$ mole of glucose-1-14 $\mathrm{C}$ cerebroside $(440,000 \mathrm{cpm}$ per $\mu \mathrm{mole}$ ), $0.8 \mathrm{mg}$ of Cutscum (isooctylphenoxypolyoxethanol ${ }^{1}$ ), and enzyme (13 to $30 \mathrm{mg}$ of protein) in a final volume of $0.65 \mathrm{ml}$. The mixtures were incubated for 1 hour at $37^{\circ} \mathrm{C}$ in air. The reaction was stopped by the addition of $0.17 \mathrm{ml}$ of $7 \%$ perchloric acid and worked up as described previously (9). The hydrolysis of glucocerebroside- ${ }^{14} \mathrm{C}$ was determined by measuring the formation of water-soluble radioactive products. Glucocerebroside itself is completely insoluble in water under these conditions. The glucocerebroside-cleaving cata-

${ }^{1}$ Fisher Scientific Co., Silver Spring, Md. 
lytic activity was found to be proportional to the amount of enzyme solution employed.

Because of the relatively large amount of glucocerebrosides that accumulates in the spleens of patients with Gaucher's disease, two techniques were employed to correct for dilution of labeled substrate. In the first procedure, the amount of endogenous glucocerebroside was quantitated by the isotope dilution technique (10). A known amount of radioactive glucocerebroside was added to samples of the enzyme preparations, and the mixtures were extracted three times with 19 vol of warm $\left(55^{\circ} \mathrm{C}\right)$ chloroform-methanol, 2:1 (vol/vol) (11). The suspensions were filtered through glass wool to remove denatured protein. One-fifth vol of water was added to the extract, and the mixtures were clarified by centrifugation. The upper phases were decanted and the lower phases equilibrated with 0.2 vol of chloroform-methanol-water, $3: 48: 47$ ( $\mathrm{vol} / \mathrm{vol} / \mathrm{vol}$ ). The upper phases were removed and the lower phases taken to dryness. The residue was saponified and partitioned as described by Kishimoto, Davies, and Radin (12). The chloroform phase was dried over anhydrous $\mathrm{Na}_{2} \mathrm{SO}_{4}$ and the solvent subsequently removed in vacuo. The residue was dissolved in a small volume of chloroform-methanol $50: 1$ and applied to a $1-\times 10-\mathrm{cm}$ column of silicic acid. The column was eluted with $30-\mathrm{ml}$ portions of chloroform-methanol, $50: 1,30: 1$, and $9: 1$. The major portion (more than $90 \%$ ) of the radioactivity was recovered in the $9: 1$ fraction. The amount of glucocerebroside was estimated colorimetrically by the phenol-sulfuric acid procedure (13) and the specific activity determined. This value, which indicated the extent of dilution of the added gluco-
TABLE I

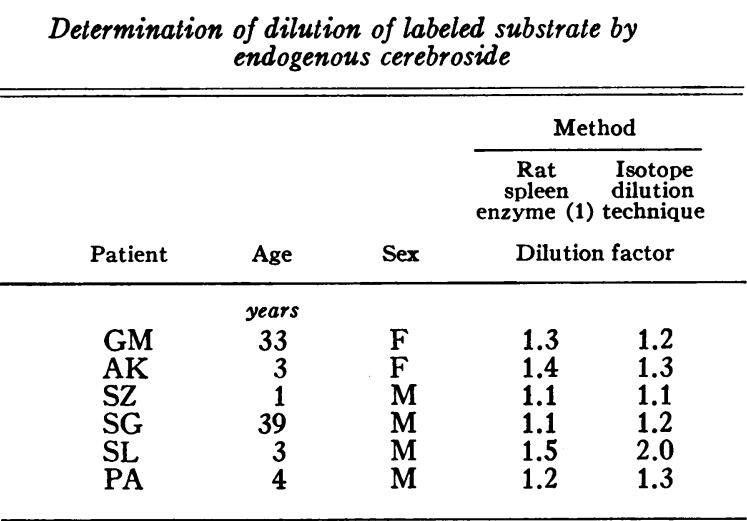

cerebroside $-{ }^{14} \mathrm{C}$, was used to calculate the quantity of endogenous glucocerebroside.

The dilution of labeled substrate was also determined by another method. This procedure consisted of measuring the amount of enzymatic hydrolysis of glucocerebroside $-{ }^{14} \mathrm{C}$ catalyzed by an enzyme preparation from rat spleen tissue, alone, and in the presence of an equal amount of the Gaucher spleen preparations (1). The decrement in the amount of radioactivity released from glucocerebroside- ${ }^{14} \mathrm{C}$ catalyzed by the combination of the two preparations was contrasted with that expected from incubating each preparation alone. The endogenous dilution was calculated from these values. The two methods gave quite good agreement in the initial six spleen samples from patients with Gaucher's disease (Table I).

TABLE II

Level of glucocerebroside-cleaving enzyme in human spleen preparations

\begin{tabular}{|c|c|c|c|c|c|c|}
\hline Condition & Patient & Age & Sex & \multicolumn{3}{|c|}{ Enzymatic activity } \\
\hline & \multicolumn{3}{|c|}{ years } & \multicolumn{3}{|c|}{ mumoles cleaved/mg protein/hr } \\
\hline Sickle cell anemia & MS & 12 & $\mathbf{F}$ & & 0.11 & (1) \\
\hline Congenital hemolytic anemia & WR & 76 & $\mathrm{~F}$ & & 0.13 & \\
\hline Hemolytic anemia & DS & 15 & $\mathrm{~F}$ & & 0.10 & \\
\hline Aplastic anemia & FB & 68 & $\mathbf{F}$ & & 0.13 & \\
\hline Tetralogy of Fallot & CD & 11 & $\mathbf{F}$ & & 0.08 & \\
\hline Mitral stenosis & ID & 40 & $\mathbf{M}$ & & 0.09 & \\
\hline Congenital spherocytosis & FA & $\begin{array}{r}40 \\
4\end{array}$ & $\mathrm{M}$ & & 0.15 & \\
\hline Idiopathic thrombocytopenic purpura & SM & 37 & $\mathrm{~F}$ & & 0.11 & \\
\hline Congenital hemolytic anemia & $\mathrm{CF}$ & 14 & $\mathrm{~F}$ & & 0.10 & \\
\hline \multirow{2}{*}{ Chronic nephritis } & RP & 21 & $\mathbf{M}$ & & 0.12 & \\
\hline & & & & Mean & 0.11 & $\pm 0.001 \mathrm{SE}$ \\
\hline \multirow{12}{*}{$\begin{array}{l}\text { Gaucher's disease, adult form } \\
\text { Gaucher's disease, adult form } \\
\text { Gaucher's disease, infantile form } \\
\text { Gaucher's disease, adult form } \\
\text { Gaucher's disease, adult form } \\
\text { Gaucher's disease, adult form } \\
\text { Gaucher's disease, adult form } \\
\text { Gaucher's disease, adult form } \\
\text { Gaucher's disease, adult form } \\
\text { Gaucher's disease, adult form } \\
\text { Gaucher's disease, adult form }\end{array}$} & GM & 33 & $\mathrm{~F}$ & & 0.008 & \\
\hline & AK & 3 & $\mathrm{~F}$ & & 0.006 & \\
\hline & $\mathrm{SZ}$ & 1 & $\mathbf{M}$ & & 0.001 & \\
\hline & SG & 39 & $\mathbf{M}$ & & 0.022 & \\
\hline & SL & 3 & $\mathbf{M}$ & & 0.010 & \\
\hline & $\mathrm{PA}$ & 4 & $\mathbf{M}$ & & 0.020 & \\
\hline & $\mathrm{JR}$ & 13 & $\mathbf{M}$ & & 0.005 & \\
\hline & TM & 5 & $\mathbf{M}$ & & 0.015 & \\
\hline & MW & 12 & $\mathrm{~F}$ & & 0.019 & \\
\hline & GK' & 14 & $\mathrm{~F}$ & & 0.021 & \\
\hline & SK】 & 15 & $\mathrm{~F}$ & & 0.032 & \\
\hline & & & & Mean & 0.015 & $\pm 0.002 \mathrm{SE}$ \\
\hline
\end{tabular}


Therefore, only the latter procedure was employed in the assays performed on the five subsequent spleen specimens. The use of the mixed rat and human enzyme preparations has the additional advantage of possibly permitting recognition of any inhibitors in the Gaucher spleen preparations.

\section{Results}

The level of glucocerebroside-cleaving enzyme in human spleen tissue was originally determined in four control and three Gaucher spleen samples (1). As additional material became available, the number of specimens in the control group was expanded to ten and those in the Gaucher's to eleven. The previous incubation time of 14 hours was reduced to 1 hour in the current study to insure that the assays were performed during a period when the rate of reaction was linear with time (9). In the previous study, the amount of enzymatic activity was expressed in terms of counts per minute of radioactive water-soluble products obtained. However, to obtain a more precise quantitative assay in the present experiment, we determined the level of endogenous glucocerebroside by two separate procedures. This knowledge permitted an accurate expression of enzymatic activity in terms of millimicromoles of substrate cleaved per milligram of protein per hour. The mean glucocerebroside-cleaving activity in preparations of spleen tissue from the ten control patients was $0.11 \mathrm{~m} \mu$ mole per $\mathrm{mg}$ of protein per hour (Table II). In enzyme preparations from eleven spleens of patients with Gaucher's disease, the mean value was $0.015 \mathrm{~m} \mu$ mole per $\mathrm{mg}$ of protein per hour. The dilution of labeled substrate by endogenous glucocerebroside in the nonGaucher's enzyme preparations was from 2 to $5 \%$. The figures for enzymatic activity in these preparations were not corrected for dilution of labeled material. However, in the Gaucher spleen enzyme preparations, the dilution of labeled substrate varied from 10 to $100 \%$. Therefore, all of the figures reported for the assays with these preparations have been corrected for endogenous dilution with the value obtained by the mixed rat and human enzyme procedure.

\section{Discussion}

The present experiments comprise a comprehensive documentation of our preliminary finding
(1) of an attenuation of glucocerebroside-cleaving enzyme in spleen tissue of patients with Gaucher's disease. Recent studies with fresh, unfrozen spleen tissue homogenized in isotonic sucrose solution indicate that a considerable portion (40 to $65 \%$ ) of the glucocerebroside-cleaving enzyme may be initially bound to subcellular particles (14). However, the activity of the enzyme in the present study was determined in the $100,000 \times g$ supernatant solutions for the following reasons. Initial experiments (9) indicated that most of the total enzymatic activity in the tissue homogenates was released in soluble form under the conditions described in these studies. The necessity for freezing the samples of spleen tissue for transportation from various parts of the country dictated the use of this procedure. The subcellular distribution of the cerebroside-cleaving enzyme was examined and found to be the same as in the non-Gaucher spleen preparations.

The results reported in a recent communication by Patrick (15) seem to substantiate our finding of a deficiency of glucocerebroside-cleaving enzyme in the Gaucher spleens. There are a number of discrepancies between the observations in the two laboratories that will have to be resolved by further experimentation. In particular, in contrast with Patrick's report of a complete absence of glucocerebroside-cleaving activity in the Gaucher's spleen preparations, in the present study there was evidence of some, albeit markedly diminished, glucocerebrosidase activity in all of the spleens from the ten examples of the adult form of Gaucher's disease. In view of the variation of time of onset of pathological signs and symptoms in patients with Gaucher's disease, it seems reasonable that varying degrees of residual enzymatic activity might be present in the adult form of this disease. No consistent proportionality could be shown in human spleen preparations between hydrolysis of glucocerebroside and artificial substrates such as $p$-nitrophenyl- $\beta$-D-glucopyranoside (9). Therefore, it would appear unlikely that the use of the latter material can give a reliable indication of the level of glucocerebroside-cleaving enzyme as proposed by Patrick. The assay employed by Patrick was based upon the determination of free glucose liberated from glucocerebroside with glucose oxidase. In the present studies, none of the radioactive products obtained from glucose- $1-{ }^{14} \mathrm{C}$ cere- 
broside after incubation with the $100,000 \times g$ supernatant enzyme preparations appeared to be free glucose (9). Almost all (95\%) of the radioactivity was retained by an anion exchange resin, suggesting conversion of the labeled reaction products to compounds such as phosphate esters or even further metabolism to various acidic products of glycolysis. The appearance of such products would probably be undetected by Patrick's procedure. In unfractionated Gaucher spleen tissue homogenates, the metabolic conversion of free glucose- $1-{ }^{14} \mathrm{C}$ to ${ }^{14} \mathrm{CO}_{2}$ was completely within normal limits.

The present observations, coupled with the earlier demonstration that cerebroside synthesis appears normal in Gaucher spleen (8), make it appear quite likely that a deficiency of activity of the glycosidic enzyme is somehow responsible for the accumulation of glucocerebroside in the reticuloendothelial cells of these patients. In view of the number of clinical differences among the infantile, adult, and possibly juvenile (16) forms of Gaucher's disease, it seems likely that there may be more than a single genetic mutation involved. Further experimentation is required to determine the extent and nature of enzymatic abnormalities in these various categories.

\section{Summary}

The level of glucocerebroside-cleaving enzyme has been determined in human spleen tissue specimens with the use of glucose- $1-{ }^{14} \mathrm{C}$ cerebroside. The level of enzymatic activity was found to be markedly attenuated in eleven preparations of Gaucher spleen tissue compared with the values observed in ten non-Gaucher spleen samples. This metabolic defect may account for the accumulation of excessive quantities of glucocerebrosides in Gaucher's disease.

\section{Acknowledgments}

The authors wish to express their deep appreciation to Drs. Janet Cuttner and Louis Wassermann of the Mount Sinai Hospital, New York, and Drs. Allen C. Crocker and Donald M. Allen, Boston, for their generous help in obtaining specimens of spleen tissue during the course of these investigations.

\section{References}

1. Brady, R. O., J. N. Kanfer, and D. Shapiro. Metabolism of glucocerebrosides. II. Evidence of an enzymatic deficiency in Gaucher's disease. Biochem. biophys. Res. Commun. 1965, 18, 221.

2. Lieb, H. Cerebrosidspeicherung bei Splenomegalie, Typus Gaucher. Hoppe-Seylers Z. physiol. Chem. 1924, 140, 305.

3. McConnell, J. S., J. C. Forbes, and F. L. Apperly. Notes on chemical studies of a Gaucher spleen. Amer. J. med. Sci. 1939, 197, 90.

4. Capper, A., H. Epstein, and R. A. Schless. Gaucher's disease. Report of a case with presentation of a table differentiating the lipoid disturbances. Amer. J. med. Sci. 1934, 188, 84.

5. Halliday, N., H. J. Deuel, Jr., L. J. Tragerman, and W. E. Ward. On the isolation of a glucose-containing cerebroside from spleen in a case of Gaucher's disease. J. biol. Chem. 1940, 132, 171.

6. Rosenberg, A., and E. Chargaff. A reinvestigation of the cerebroside deposited in Gaucher's disease. J. biol. Chem. 1958, 233, 1323.

7. Agranoff, B. W., N. Radin, and W. Suomi. Enzymic oxidation of cerebrosides : studies on Gaucher's disease. Biochim. biophys. Acta (Amst.) 1962, 57, 194.

8. Trams, E. G., and R. O. Brady. Cerebroside synthesis in Gaucher's disease. J. clin. Invest. 1960, 39, 1546.

9. Brady, R. O., J. Kanfer, and D. Shapiro. The metabolism of glucocerebrosides. I. Purification and properties of a glucocerebroside-cleaving enzyme from spleen tissue. J. biol. Chem. 1965, 240, 39.

10. Aronoff, S. Techniques of Radiobiochemistry. Ames, Iowa State College Press, 1956.

11. Folch, J., M. Lees, and G. H. Sloane-Stanley. A simple method for the isolation and purification of total lipides from animal tissues. J. biol. Chem. 1957, 226, 497.

12. Kishimoto, Y., W. E. Davies, and N. S. Radin. Turnover of the fatty acids of rat brain gangliosides, glycerophosphatides, cerebrosides, and sulfatides as a function of age. J. Lipid Res. 1965, 6, 525.

13. Dubois, M., K. A. Gilles, J. K. Hamilton, P. A. Rebers, and F. Smith. Colorimetric method for determination of sugars and related substances. Analyt. Chem. 1956, 28, 350.

14. Kampine, J. P., J. N. Kanfer, and R. O. Brady. Unpublished observations.

15. Patrick, A. D. A deficiency of glucocerebrosidase in Gaucher's disease. Biochem. J. 1965, 97, 17 C.

16. Herrlin, K.-M., and P. O. Hillborg. Neurological signs in a juvenile form of Gaucher's disease. Acta paediat. (Uppsala) 1962, 51, 137. 